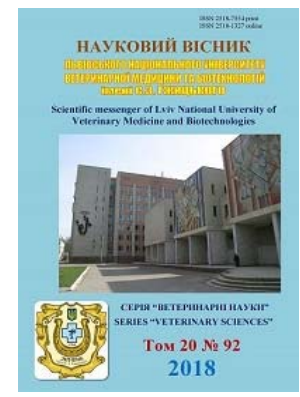

\author{
Науковий вісник Дьвівського національного університету \\ ветеринарної медицини та біотехнологій імені С.3. Гжицького
}

\author{
Scientific Messenger of Lviv National University \\ of Veterinary Medicine and Biotechnologies
}

UDC 619:616.98:619:616.08 (477.83)

\title{
Circulating microflora and its resistance to antibacterial medications in the conditions of Farm "Pchani-Denkovich" of Zhydachiv district of Lviv region
}

\author{
Ya.V. Kisera, L.Ya. Bozhyk, Yu.G. Storchak \\ Stepan Gzhytskyi National University of Veterinary Medicine and Biotechnologies of Lviv, Ukraine
}

Article info

Received 08.10.2018

Received in revised form 08.11 .2018

Accepted 09.11.2018

Stepan Gzhytskyi National University of Veterinary Medicine and Biotechnologies of Lviv. Pekarska str., 50, Lviv , 79010, Ukraine.

Tel.: +38-067-606-58-25

E-mail: kisera53@ukr.net. lbozyk31@gmail.com juliettus1@gmail.com
Kisera, Ya.V., Bozhyk, L.Ya., \& Storchak, Yu.G. (2018). Circulating microflora and its resistance to antibacterial medications in the conditions of Farm "Pchani-Denkovich" of Zhydachiv district of Lviv region. Scientific Messenger of Lviv National University of Veterinary Medicine and Biotechnologies, 20(92), 13-17. doi: 10.32718/nvlvet9203

The importance of the influence of microorganisms on the health of humans and animals is beyond doubt. In recent decades, a large amount of data on the interaction of the flora with the elements of the immune system has been accumulated. Therefore, it is important to identify any hazardous factors that must be prevented or neutralized. One of such factors is the circulating flora of the premises, the organism of the animal, its virulence and resistance to antibacterial drugs. Bacteriological studies included bacteriological culture on the nutrient environment, their identification and the study of antibioticsensitivity. According to the results of bacteriological studies of milk samples, it was found that in 25\% of the studied samples Staphylococcus aureus cultures were found in different concentrations. In 4 samples, Proteus vulgaris was detected. Bacteriological studies of vaginal exudate from the cows after calving have shown that they have Escherichia coli, Escherichia coli haemolitica, Staphylococcus aureus, Streptococcus haemolyticus, Staphylococcus epidermidis, Enterobacter cloacae, Proteus vulgaris, mold fungi of the Aspergillus spp. The studies of the exudate from the nasal passages and the mouthof the calves found that all the tested samples contained Escherichia coli, Proteus vulgaris, Staphylococcus epidermidis, Enterococcus spp., Klebsiella pnemoniae and Aspergillus and Candida fungi. The results of calf excrement studies revealed the presence of a number of microorganisms: Escherichia coli, Escherichia coli haemolitica, Proteus vulgaris, Staphylococcus epidermidis, Enterobacter cloacae and Enterobacter faecalis in different percentages. In determining the sensitivity of isolated cultures to antibacterial drugs, it has been established that Staphylococcus aureus cultures are sensitive to all antibiotics; Proteus vulgaris show resistance to ampicillin, amoxicillin; Escherichia coli haemolytica is resistant to ampicillin.

Key words: cattle, milk, vaginal, nasal, mouth, excrement flora, Escherichia coli, Escherichia coli haemolitica, Proteus vulgaris, Staphylococcus epidermidis, Enterobacter cloacae, Enterobacter faecalis, Enterococcus spp., Klebsiella pnemoniae, fungi of the genus Aspergillus and Candida; antibacterial medication; resistance.

\section{Циркулююча мікрофлора та її стійкість до антибактеріальних препаратів в умовах ФГ “Пчани-Денькович” Жидачівського району Львівської області}

\author{
Я.В. Кісера, Л.Я. Божик, Ю.Г. Сторчак \\ Львівський національний університет ветеринарної медицини та біотехнологій імені С.3. Гжицького, \\ м. Львів, Украӥна
}

Важливість впливу мікроорганізмів на стан здоров'я людини і тварин не викликає сумнівів. В останні десятиліття накопичено велику кількість даних щуодо взаємодії мікрофлори з елементами імунної системи. Тому, важливим є виявлення будь-яких небезпечних факторів, яким треба запобігати чи нейтралізувати їх. Одним із таких факторів яким ииркулююча мікрофлора приміщень, організму тварини, ї̈ вірулентність та резистентність до антибактеріальних препаратів. Бактеріологічні дослідження включали в себе посів досліджуваного матеріалу на живильні середовища, їх ідентифікачію та вивчення чутливості до антибіотиків. За результатами бактеріологічних досліджень проб молока встановлено, щзо в 25\% досліджуваних пробах виділено культури Staphylococcus aureus в різних кониентрачіях. У 4-х пробах встановлено наявність Proteus vиlgaris. Бактеріологічні дослідження 
ексудату з піхви, відібраного у корів після отелу, засвідчили наявність у них Escherichia coli, Escherichia coli haemolitica, Staphylococcus aureus, Streptococcus haemolyticus, Staphylococcus epidermidis, Enterobacter cloacae, Proteus vulgaris, nлiceневих грибів poдy Aspergillus spp. Дослідженнями ексудату з носових ходів та зіву у телят встановлено, щуо у всіх досліджуваних пробах наявні Escherichia coli, Proteus vulgaris, Staphylococcus epidermidis, Enterococcus spp., Klebsiella pneтопiae ma zpuби poдiв Aspergillus ma Candida. Результатами досліджень калу телят встановлена наявність низки мікроорганізмів: Escherichia coli, Escherichia coli haemolitica, Proteus vulgaris, Staphylococcus epidermidis, Enterobacter cloacae ma Enterobacter faecalis y piзних відсоткових cniввідношеннях. При визначенні чутливості виділених культур до антибактеріальних препаратів встановлено, цио культури Staphylococcus aureus є чутливими до всіх антибіотиків; Рroteus vulgaris проявив стійкість до ампіциліну, амоксицикліну; Escherichia coli haemolytica резистентна до ампіциліну.

Ключові слова: велика рогата худоба; мікрофлора молока, піхви, слизової носа, зіву $і$ вмісту калу; Escherichia coli, Escherichia coli haemolitica, Proteus vulgaris, Staphylococcus epidermidis, Enterobacter cloacae, Enterobacter faecalis, Enterococcus spp., Klebsiella pпетопіае, гриби родів Aspergillus та Candida; антибактеріальні препарати; стійкість.

\section{Вступ}

Факторами, що сприяють виникненню асоціативних захворювань, є застосування інтенсивних технологій, недотримання санітарно-гігієнічних правил утримання та надмірне скупчення тварин. Доведено, що домінуюче значення мають умовно патогенні бактерії в розвитку інфекційної патології тварин, які спричиняють факторні інфекції, що складає 81,4\% випадків від усіх захворювань (Peleno, 2012).

3 точки зору безпеки харчових продуктів E. coli $€$ небезпечним чинником, що впливає на їхню якість (Bean and Griffin, 1990; Mead et al., 1999; Bryan, 2001). Штами E. coli викликають різні захворювання у людини та тварин. Гемолітична E. coli може призвести до геморагічного коліту, гемолітичного уремічного синдрому та тромботичної тромбоцитопенічної хвороби. В організмі здорової великої рогатої худоби Escherichia coli може знаходитися у допустимій концентрації до $10^{7}$ КУО, Escherichia coli haemolitica в організмі тварин у нормі не повинно бути (Dorn, 1993; Boyce et al., 1995).

3 метою збереженості молодняку тварин, підвищення опірності імунної системи організму необхідно проводити дослідження циркулюючої в умовах господарств мікрофлори. Визначення видового складу циркулюючої мікрофлори, іiі вірулентність та стійкість до антибактеріальних препаратів $є$ важливим фактором біологічного захисту (Holovko, 2009; Kisera et al., 2017).

Mета $i$ завдання досліджень: в умовах ФГ "Пчани-Денькович" с. Пчани Жидачівського району Львівської області дослідити видовий склад циркулюючої бактеріальної мікрофлори та її резистентність до антибактеріальних препаратів. Для досягнення даної мети були поставлені такі завдання: провести бактеріологічні дослідження змивів з носа, зіву, калу, відібраних від телят; молока та ексудату із матки корів після отелу; вивчити морфологічні властивості бактеріальної мікрофлори та визначити чутливість до антибіотиків.

\section{Матеріал та методи досліджень}

Дослідження проводились у ФГ “ПчаниДенькович” Жидачівського району Львівської області, в умовах кафедри епізоотології Львівського національного університету ветеринарної медицини та біоте- хнологій імені С.3. Гжицького. Для дослідження корів після отелу відбирали молоко та ексудат 3 піхви, від телят 2-тижневого віку - змиви з носа, зіву та калу. У дослідах було задіяно 20 корів та 20 телят симентальської породи.

Бактеріологічні дослідження проводились за методикою Висоцького А.С. із співавторами, які включали посів досліджуваного матеріалу на живильні середовища, висів отриманих культур на диференціальні середовища 3 метою визначення їхніх морфологічних властивостей, вивчення їхньої чутливості до антибіотиків (Vysockij and Baranovskaja, 2002; Guardabassi, 2008; Levkivska et al., 2017). Для вивчення антибіотикочутливості ізоляти висівали на середовище АГВ та використовували диски 3 антибактеріальними препаратами.

\section{Результати та їх обговорення}

Результати бактеріологічних досліджень молока (табл.1) показали наявність умовно-патогенної та патогенної мікрофлори у пробах, відібраних від корів господарства. Так, у 45\% досліджуваних проб виявлено Escherichia coli, концентрація якої була в межах $10^{2}-10^{5}$. В 20\% досліджуваних пробах виділено культури Staphylococcus aureus концентрацією $10^{2}$ та 5\%$10^{3}$ відповідно. У 4-х пробах встановлено наявність Proteus vulgaris. У двох пробах були виділені Staphylococcus epidermidis, Streptococcus haemolyticus та Enterococcus faecalis.

При дослідженні матеріалу, відібраного 3 піхви корів після отелу (табл. 2) встановили наявність у них Escherichia coli в 5-ти досліджуваних пробах, Streptococcus haemolyticus - в 3-х пробах, Staphylococcus epidermidis - в 6-ти пробах, Enterobacter cloacae - в 4х досліджуваних пробах. За результатами дослідження встановлено наявність Escherichia coli haemolitica, Staphylococcus aureus, Proteus vulgaris, плісеневих грибів роду Aspergillus spp., яких в нормі не повинно бути.

Бактеріологічні дослідження ексудату 3 носових ходів та зіву в телят (табл. 3) показали наявність E. coli у 55\% проб. У 4-х пробах виявили гриби роду Aspergillus spp. та Candida. В 5-ти пробах виявили Staphylococcus epidermidis та Enterococcus spp. Klebsiella pnemoniae була зафіксована у 3-х досліджуваних пробах. 
Таблиця 1

Концентрація мікроорганізмів, виділених з молока, КУО, n = 20

\begin{tabular}{|c|c|c|c|c|c|c|}
\hline $\begin{array}{l}\text { № } \\
\text { 3/ח }\end{array}$ & $\begin{array}{c}\text { Staphylococcus } \\
\text { epidermidis }\end{array}$ & $\begin{array}{c}\text { Escherichia } \\
\text { coli }\end{array}$ & $\begin{array}{c}\text { Staphylococcus } \\
\text { aureus }\end{array}$ & $\begin{array}{l}\text { Proteus } \\
\text { vulgaris }\end{array}$ & $\begin{array}{c}\text { Enterococcus } \\
\text { faecalis }\end{array}$ & $\begin{array}{l}\text { Streptococcus } \\
\text { haemolyticus }\end{array}$ \\
\hline 1 & $10^{5}$ & - & $10^{3}$ & - & - & - \\
\hline 2 & - & + & $10^{2}$ & - & $10^{4}$ & - \\
\hline 3 & - & $10^{2}$ & - & - & $10^{2}$ & $10^{4}$ \\
\hline 4 & - & $10^{2}$ & $10^{2}$ & $10^{2}$ & - & - \\
\hline 5 & - & $10^{5}$ & - & $10^{2}$ & - & - \\
\hline 6 & - & - & - & - & - & - \\
\hline 7 & - & - & - & - & - & - \\
\hline 8 & - & $10^{2}$ & - & - & - & - \\
\hline 9 & - & $10^{2}$ & - & - & - & - \\
\hline 10 & - & $10^{5}$ & $10^{2}$ & - & - & - \\
\hline 11 & - & + & - & - & - & - \\
\hline 12 & - & $10^{5}$ & - & - & - & $10^{3}$ \\
\hline 13 & - & - & - & - & - & - \\
\hline 14 & - & $10^{2}$ & - & $10^{2}$ & - & - \\
\hline 15 & - & $10^{2}$ & - & - & - & - \\
\hline 16 & $10^{5}$ & - & - & - & - & - \\
\hline 17 & - & - & - & - & - & - \\
\hline 18 & - & + & $10^{2}$ & - & - & - \\
\hline 19 & - & - & - & - & - & - \\
\hline 20 & - & + & - & $10^{2}$ & - & - \\
\hline
\end{tabular}

Таблиця 2

Виділена мікрофлора з піхви корів після отелу, КУО, $\mathrm{n}=20$

\begin{tabular}{|c|c|c|c|c|c|c|c|c|}
\hline $\begin{array}{l}\text { № } \\
\Pi / \Pi\end{array}$ & $\begin{array}{c}\text { Staphylococcus } \\
\text { epidermidis }\end{array}$ & $\begin{array}{c}\text { Escherichia } \\
\text { coli }\end{array}$ & $\begin{array}{c}\text { Escherichia coli } \\
\text { haemolitica }\end{array}$ & $\begin{array}{c}\text { Enterobacter } \\
\text { cloacae }\end{array}$ & $\begin{array}{c}\text { Staphylococcus } \\
\text { aureus }\end{array}$ & $\begin{array}{l}\text { Proteus } \\
\text { vulgaris }\end{array}$ & $\begin{array}{c}\text { Aspergillus } \\
\text { spp. }\end{array}$ & $\begin{array}{l}\text { Streptococcus } \\
\text { haemoly ticus }\end{array}$ \\
\hline 1 & - & $10^{2}$ & + & - & - & - & - & $10^{2}$ \\
\hline 2 & $10^{4}$ & & - & - & - & $10^{2}$ & - & - \\
\hline 3 & $10^{3}$ & $10^{2}$ & - & - & - & - & - & - \\
\hline 4 & - & + & - & $10^{3}$ & - & - & - & - \\
\hline 5 & - & - & - & $10^{3}$ & + & - & + & - \\
\hline 6 & - & - & + & - & - & - & - & - \\
\hline 7 & - & $10^{2}$ & - & - & - & - & - & - \\
\hline 8 & - & + & - & - & - & - & - & - \\
\hline 9 & $10^{3}$ & + & - & - & - & - & - & - \\
\hline 10 & - & - & - & - & - & $10^{2}$ & + & - \\
\hline 11 & $10^{3}$ & - & - & - & - & - & - & - \\
\hline 12 & - & - & - & - & - & - & - & $10^{2}$ \\
\hline 13 & - & - & - & $10^{3}$ & + & - & - & - \\
\hline 14 & - & $10^{2}$ & - & - & - & - & - & - \\
\hline 15 & - & + & - & - & - & $10^{2}$ & - & - \\
\hline 16 & - & $10^{2}$ & - & - & - & - & - & - \\
\hline 17 & - & - & - & - & - & - & - & $10^{3}$ \\
\hline 18 & $10^{2}$ & - & - & - & - & - & - & - \\
\hline 19 & $10^{3}$ & - & - & - & - & - & - & - \\
\hline 20 & - & - & - & $10^{3}$ & - & - & + & - \\
\hline
\end{tabular}

Таблиця 3

Концентрація мікроорганізмів, виділених 3 носа і зіву телят, КУО, n $=20$

\begin{tabular}{|c|c|c|c|c|c|c|}
\hline № 3/ח & $\begin{array}{c}\text { Staphylococcus } \\
\text { epidermidis }\end{array}$ & Escherichia coli & Aspergillus & Enterococcus spp. & Candida & $\begin{array}{l}\text { Klebsiella } \\
\text { pnemoniae }\end{array}$ \\
\hline 1 & $10^{2}$ & $10^{2}$ & + & - & - & - \\
\hline 2 & - & + & - & $10^{4}$ & + & - \\
\hline 3 & $10^{2}$ & + & - & - & - & \\
\hline 4 & - & + & - & - & - & \\
\hline 5 & - & $10^{2}$ & - & $10^{2}$ & - & \\
\hline 6 & - & - & - & - & - & $10^{2}$ \\
\hline 7 & - & - & - & - & - & - \\
\hline 8 & - & - & - & $10^{4}$ & - & - \\
\hline 9 & - & - & + & - & - & - \\
\hline 10 & - & $10^{2}$ & - & - & - & - \\
\hline
\end{tabular}




\begin{tabular}{|c|c|c|c|c|c|c|}
\hline 11 & - & - & - & - & - & $10^{2}$ \\
\hline 12 & $10^{2}$ & + & + & - & + & - \\
\hline 13 & - & - & - & - & - & - \\
\hline 14 & - & + & - & - & + & - \\
\hline 15 & - & - & - & - & + & - \\
\hline 16 & - & + & - & $10^{2}$ & - & - \\
\hline 17 & - & - & + & - & - & - \\
\hline 18 & $10^{2}$ & $10^{2}$ & - & - & - & - \\
\hline 19 & - & - & - & $10^{3}$ & - & - \\
\hline 20 & $10^{2}$ & + & - & - & - & $10^{2}$ \\
\hline
\end{tabular}

При дослідженні мікрофлори, виділеної із калу у телят (табл. 4), встановлено наявність Staphylococcus epidermidis, Enterobacter cloacae та Enterobacter faecalis у 20\% досліджуваних пробах. Escherichia coli наявна у всіх пробах, проте у 15\% 3 них була на межі граничної допустимої концентрації. У 5-ти пробах встановлено наявність Escherichia coli haemolitica. У 3-х пробах виявлено Staphylococcus aureus та Proteus vulgaris.

\section{Таблиця 4}

Концентрація мікроорганізмів виділених із калу у телят, КУО, n $=20$

\begin{tabular}{|c|c|c|c|c|c|c|c|}
\hline № 3/ח & $\begin{array}{c}\text { Staphylococcus } \\
\text { epidermidis }\end{array}$ & $\begin{array}{c}\text { Staphylococcus } \\
\text { aureus }\end{array}$ & $\begin{array}{c}\text { Escherichia } \\
\text { coli }\end{array}$ & $\begin{array}{c}\text { Escherichia coli } \\
\text { haemolitica }\end{array}$ & $\begin{array}{l}\text { Proteus } \\
\text { vulgaris }\end{array}$ & $\begin{array}{c}\text { Enterobacter } \\
\text { cloacae }\end{array}$ & $\begin{array}{c}\text { Enterobacter } \\
\text { faecalis }\end{array}$ \\
\hline 1 & $10^{2}$ & + & $10^{6}$ & $10^{3}$ & - & - & - \\
\hline 2 & - & - & $10^{6}$ & - & - & - & - \\
\hline 3 & - & - & $10^{4}$ & $10^{2}$ & $10^{2}$ & - & - \\
\hline 4 & - & - & $10^{7}$ & - & - & - & - \\
\hline 5 & - & - & $10^{5}$ & - & - & $10^{2}$ & $10^{4}$ \\
\hline 6 & $10^{2}$ & - & $10^{6}$ & - & - & - & - \\
\hline 7 & - & - & $10^{4}$ & - & - & - & $10^{2}$ \\
\hline 8 & - & - & $10^{7}$ & - & - & - & - \\
\hline 9 & $10^{2}$ & - & $10^{5}$ & - & - & - & - \\
\hline 10 & - & + & $10^{6}$ & $10^{2}$ & - & - & - \\
\hline 11 & - & - & $10^{4}$ & - & - & - & - \\
\hline 12 & - & - & $10^{4}$ & - & - & $10^{2}$ & $10^{3}$ \\
\hline 13 & - & + & $10^{4}$ & $10^{2}$ & - & - & - \\
\hline 14 & - & - & $10^{6}$ & - & - & - & - \\
\hline 15 & & - & $10^{4}$ & - & $10^{2}$ & - & - \\
\hline 16 & - & - & $10^{4}$ & - & $10^{2}$ & - & - \\
\hline 17 & - & - & $10^{4}$ & - & - & $10^{3}$ & - \\
\hline 18 & $10^{2}$ & - & $10^{6}$ & - & - & - & - \\
\hline 19 & - & - & $10^{4}$ & - & - & $10^{3}$ & - \\
\hline 20 & - & - & $10^{7}$ & $10^{2}$ & - & - & $10^{4}$ \\
\hline
\end{tabular}

При визначенні чутливості виділених культур до антибактеріальних препаратів (табл. 5) встановлено, що Staphylococcus aureus чутливий до всіх антибіотиків; Proteus vulgaris виявив стійкість до ампіциліну, амоксицикліну та чутливість до цефотоксиму, цефтрі- аксону, цефтазидиму, гентаміцину, іміпінему, цефенілу, цефоперазону, амікацину; Escherichia coli haemolytica резистентна до ампіциліну. До всіх інших досліджуваних антимікробних препаратів виявила чутливість.

\section{Таблиця 5}

Чутливість виділених культур до антибактеріальних препаратів

\begin{tabular}{|c|c|c|c|}
\hline $\begin{array}{c}\text { Назва антибактеріального } \\
\text { препарату }\end{array}$ & Staphylococcus aureus & Proteus vulgaris & Escherichia coli haemolytica \\
\hline Ампіцилін & Ч & $\mathrm{P}$ & $\mathrm{P}$ \\
\hline Амоксициклін & Ч & $\mathrm{P}$ & Ч \\
\hline Цефотоксим & Ч & Ч & Ч \\
\hline Цефтріаксон & Ч & Ч & Ч \\
\hline Цефтазидим & Ч & Ч & Ч \\
\hline Гентаміцин & Ч & Ч & Ч \\
\hline Іміпінем & Ч & Ч & Ч \\
\hline Цефенім & Ч & Ч & Ч \\
\hline Цефоперазон & Ч & Ч & Ч \\
\hline Амікацин & Ч & Ч & Ч \\
\hline
\end{tabular}

*Примітка: Ч - чутливі до антибактеріального препарату; Р - резистентні (стійкі) до антибактеріального препарату 
Отже, результати досліджень засвідчили, що в умовах господарства серед великої рогатої худоби циркулює така мікрофлора: Staphylococcus aureus, Staphylococcus haemoliticus, Streptococcus epidermidis, Proteus vulgaris, Enterobacter cloacae, Enterobacter faecalis, Escherichia coli, Escherichia coli haemolitica, Klebsiella pnemoniae, плісеневі гриби роду Aspergillus та дріжджові гриби роду Candida. Встановлено, що досліджувані культури чутливі до більшості досліджуваних антибіотибактеріальних препаратів, що свідчить про відсутність резистентності до антибіотиків через неконтрольоване їх використання.

\section{Висновки}

1. Бактеріологічним дослідженнями молока та ексудату з піхви, відібраних від корів після отелу, встановлена наявність Staphylococcus epidermidis, Staphylococcus aureus, Streptococcus haemolyticus, Enterobacter cloacae, Enterobacter faecalis, Escherichia coli та Proteus vulgaris.

2. Зі змивів з носа та зіву, відібраних від телят, виділено Escherichia coli, Staphylococcus epidermidis, Enterococcus spp., Klebsiella pnemoniae та гриби родів Aspergillus та Candida.

3. У пробах калу телят виявлено Escherichia coli, Escherichia coli haemolitica, Proteus vulgaris, Staphylococcus aureus, Staphylococcus epidermidis, Enterobacter cloacae та Enterobacter faecalis.

4. Досліджувані культури мікроорганізмів є чутливими до більшості антибактеріальних препаратів.

Перспективи подальших досліджень полягають у подальшому ретельному моніторингу циркулюючої мікрофлори 3 метою розробки рекомендацій щодо профілактики захворювань великої рогатої худоби в умовах ФГ “Пчани-Денькович” Жидачівського району Львівської області.

\section{References}

Peleno, R.A. (2012). Epizootolohichnyi monitorynh khvorob svynei V Ukraini. Veterynarna biotekhnolohiia, 21, 330-335 (in Ukrainian).
Bean, N.H., \& Griffin, P.M.G. (1990). Foodborne disease outbreaks in the US 1973-1987: Pathogens, vehicles, and trends. J. Food Prot. 53(9), 804-817. doi: 10.4315/0362-028X-53.9.804.

Mead, P.S., Slutsker, L., Dietz, V., McCraig, L.F., Bresee, J.S., Shapiro, C., Griffin, P.M., \& Tauxe, R.V. (1999). Food-related illness and death in the United States. Emerg. Infect. Dis., 5(5), 607-625. doi: 10.3201/eid0505.990502.

Bryan, F.L. (2001). Reflections on a career in public health: Evolving foodborne pathogens, environmental health, and food safety programs. J. Environ. Health, 65(5), 14 24. https://www.ncbi.nlm.nih.gov/pubmed/12491850.

Dorn, C.R. (1993). Review of food borne outbreak of Escherichia coli O157:H7 infection in the western United States. J. Am. Vet. Med. Assoc. 203(11), 15831587. https://www.ncbi.nlm.nih.gov/pubmed/8288484.

Boyce, T.G., Swerdlow, D.L., \& Griffin, P.M. (1995). Escherichia coli O157:H7 and the hemolyt-icuremic syndrome. N. Engl. J. Med. 333, 364-368. doi: 10.1056/NEJM199508103330608.

Holovko, A.M. (2009). Biolohichna ta henetychna bezpeka Ukrainy Mizhvid. nauk. temat. zbirnyk. "Veterynarna medytsyna". Kharkiv, 92, 10-13 (in Ukrainian).

Vysockij, A.Je., \& Baranovskaja, Z.N. (2002). Spravochnik po bakteriologicheskim metodam izyskanij v veterinarii. Izdatel'stvo Ministerstva sel'skogo hozjajstva Respubliki Belarus' (in Russian).

Levkivska, N.D., Kurtiak, B.M., Levkivskyi, D.M., Padovskyi, A.I., Gutyj, B.V., \& Semaniuk, V.I. (2017). Laboratorna diahnostyka infektsiinykh khvorob tvaryn bakterialnoi etiolohii. Lviv: SPOLOM (in Ukrainian).

Guardabassi, L. (2008). Guide to Antimicrobial Use in Animals. Blackwell Publishing. https://onlinelibrary. wiley.com/doi/book/10.1002/9781444302639.

Kisera, Y.V., Storchak, Y.G., \& Bozhyk, L.Y. (2017). Vydovyi sklad tsyrkuliuiuchoi mikroflory ta yii stiikist do antybakterialnykh preparativ $\mathrm{v}$ umovakh PAF "Berezhnytsia" Zhydachivskoho raionu Lvivskoi oblasti Nauk. visnyk LNUVMB im. S.Z. Hzhytskoho, 19(78), 172-176. doi: 10.15421/nvlvet7835 (in Ukrainian). 